\title{
The Must Farm pile-dwelling settlement
}

\author{
Mark Knight ${ }^{1, *}$, Rachel Ballantyne ${ }^{2}$, Iona Robinson Zeki ${ }^{1}$ \\ $\&$ David Gibson ${ }^{1}$
}

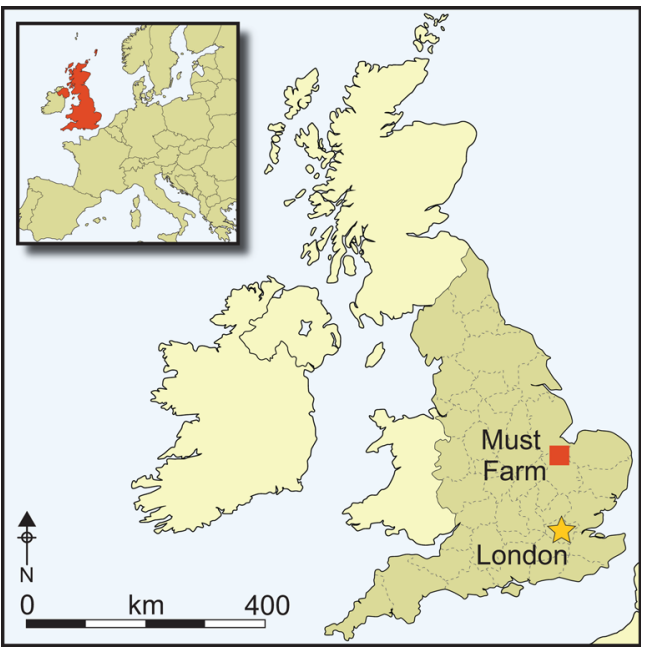

The Must Farm pile-dwelling site is an extraordinarily well-preserved Late Bronze Age settlement in Cambridgeshire, UK. The authors present the site's contextual setting, from its construction, occupation and subsequent destruction by fire in relatively quick succession. A slow-flowing watercourse beneath the pile-dwellings provided a benign burial environment for preserving the debris of construction, use and collapse, while the catastrophic manner of destruction introduced a definitive timeframe. The scale of its occupation speaks to the site's exceptional nature, enabling the authors to deduce the everyday flow and use of things in a prehistoric domestic setting.

Keywords: Britain, Bronze Age, pile-dwelling, material intensity, temporality

\section{Introduction}

Recent excavations near Whittlesey in eastern England have uncovered a Late Bronze Age (1100-800 cal BC) occupation site, comprising wooden structures built over a freshwater palaeochannel — the Must Farm pile-dwelling settlement (Figure 1). Its destruction by a catastrophic fire has provided an exceptional opportunity to investigate how people inhabited and affected their world in the final decades of the Bronze Age in Britain. The soft, waterlogged fluvial silts have preserved extensive structural remains and diverse material culture, including delicate organics, such as textiles and foodstuffs. These are the most completely preserved prehistoric domestic structures found in Britain, and are comparable to the lake-dwellings

1 Cambridge Archaeological Unit, Department of Archaeology, University of Cambridge, Downing Street, Cambridge CB2 3DZ, UK

2 McDonald Institute for Archaeological Research, University of Cambridge, Downing Street, Cambridge CB2 3ER, $U K$

* Author for correspondence (Email:mk226@cam.ac.uk)

(C) Antiquity Publications Ltd, 2019. This is an Open Access article, distributed under the terms of the Creative Commons Attribution-NonCommercial-NoDerivatives licence (http://creativecommons.org/licenses/by-nc-nd/ $4.0 /$ ), which permits non-commercial re-use, distribution, and reproduction in any medium, provided the original work is unaltered and is properly cited. The written permission of Cambridge University Press must be obtained for commercial re-use or in order to create a derivative work.

ANTIQUITY 93369 (2019): 645-663

https://doi.org/10.15184/aqy.2019.38 


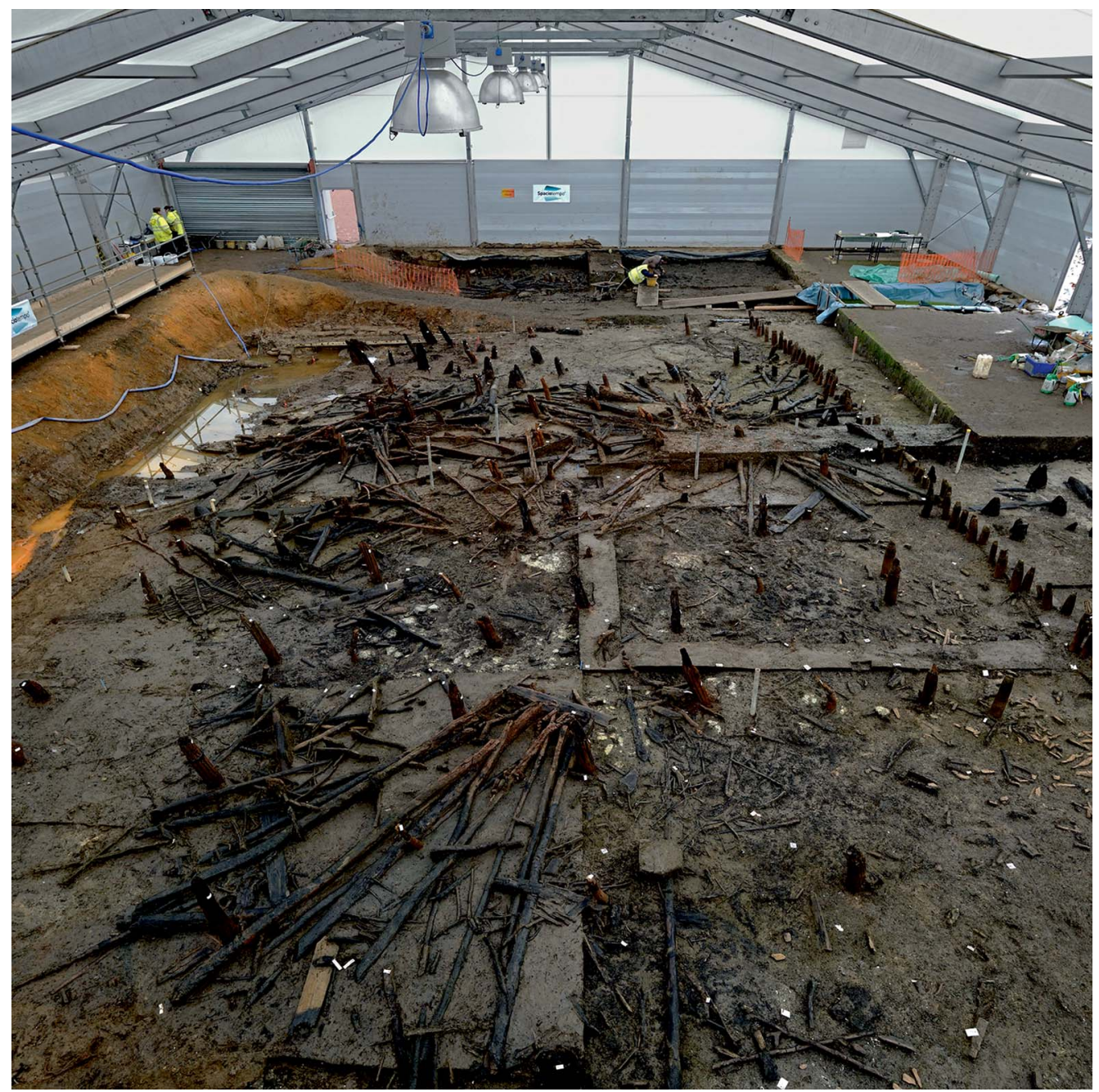

Figure 1. Excavation of the Must Farm pile-dwelling settlement, showing the main body of the collapsed settlement (looking east) in its river-silt matrix (photograph by D. Webb).

of the Circum-Alpine region in terms of their architectural detail, material diversity and spatial-temporal definition.

After describing the discovery, setting and character of the remains, we present lines of evidence that suggest this settlement existed for months, rather than decades. Contrary to the extensive media coverage at the time of excavation, which portrayed the site as a 'Pompeii of the Fens' (e.g. Glass 2016; Gray 2016), implying a perfectly preserved moment in time, we describe a site with a lived - albeit short-duration. The brevity of occupation magnifies the quantity of materials in daily 'use' as circulated, stored, processed or consumed resources_a phenomenon henceforth described as 'material intensity'. Our interpretation puts into perspective patterns of deposition in prehistoric landscapes, such as the surrounding Flag Fen Basin, and enables us to address "how little, and how unrepresentative, is the sample of (C) Antiquity Publications Ltd, 2019 
deposited material recovered archaeologically compared with that which was actually in circulation" (Barrett 2012: 15).

\section{The palaeolandscape of the Flag Fen Basin}

The remains of the pile-dwelling settlement were located within the silts of a slow-flowing freshwater river, a distributary of the later Early Bronze Age to Iron Age River Nene, which followed the course of an earlier Bronze Age tidal channel (Robinson et al. 2015). The palaeochannel lies on the southern edge of the Flag Fen Basin (Figure 2) — an embayment on the western edge of the Fens that has long been recognised for its later prehistoric landscape (Pryor 2001). The deep, laminated sands and silts deposited by the earlier tidal creek formed a pronounced, consolidated sinuous feature within the fen basin (a formation known locally as a 'roddon') that acted as the retaining banks of the later freshwater channel. This freshwater channel provided a navigable conduit along the southern edge of the Flag Fen Basin - a region that became increasingly wet and peaty as groundwater levels rose during the Bronze and Iron Ages (French 2003: 108).

Between 2009 and 2012, thorough investigations of a $325 \mathrm{~m}$ stretch of the palaeochannel to the west of the pile-dwelling settlement exposed the remains of nine logboats (eight Bronze Age, one Iron Age), a series of Middle Bronze Age fish weirs and fish traps and several items of Bronze and Iron Age weaponry. Dating to 1700-100 BC, the palaeochannel was active throughout the construction and use of the adjacent Fengate and Bradley Fen field systems, the Flag Fen post-alignments and the Iron Age settlements of King's Dyke, Bradley Fen and Cat's Water (Pryor 2001; Evans et al. 2009; Knight \& Brudenell in press). This later prehistoric landscape is buried under $1-4 \mathrm{~m}$ of peats and silts, and is only exposed during deep interventions, such as quarrying. While this depth of burial helps to protect and preserve archaeological remains, it also obscures their visibility in the present-day landscape.

\section{Discovery}

The presence of timber piles on the edge of the disused Must Farm Quarry Pit was first observed in 1999 by local archaeologist Martin Redding. During subsequent visits, he retrieved later prehistoric potsherds, worked flint and metalwork from exposed sediment around the piles. Plans to reopen the quarry pit led to the commissioning of the Cambridge Archaeological Unit (CAU) to undertake an archaeological evaluation of the local landscape. In 2004, an initial, small-scale exploration of the timber piles revealed a $2.2 \mathrm{~m}$-long alignment of 12 wooden piles driven into palaeochannel silts. Samples from three of the piles were radiocarbon dated to the Late Bronze Age (Table 1: piles 1, 7 \& 14).

In 2006, an intensive, site-specific evaluation undertaken by the CAU opened two large trenches. The previously identified alignment of piles was revealed to form part of an enclosing palisade of a pile-dwelling settlement constructed over a freshwater channel. The material remains were dominated by waterlogged and charred timbers and an extraordinary assemblage of 'intact' Late Bronze Age material culture (Knight 2009). A major conflagration event appeared to have destroyed the settlement, as most of the remains were

(C) Antiquity Publications Ltd, 2019 


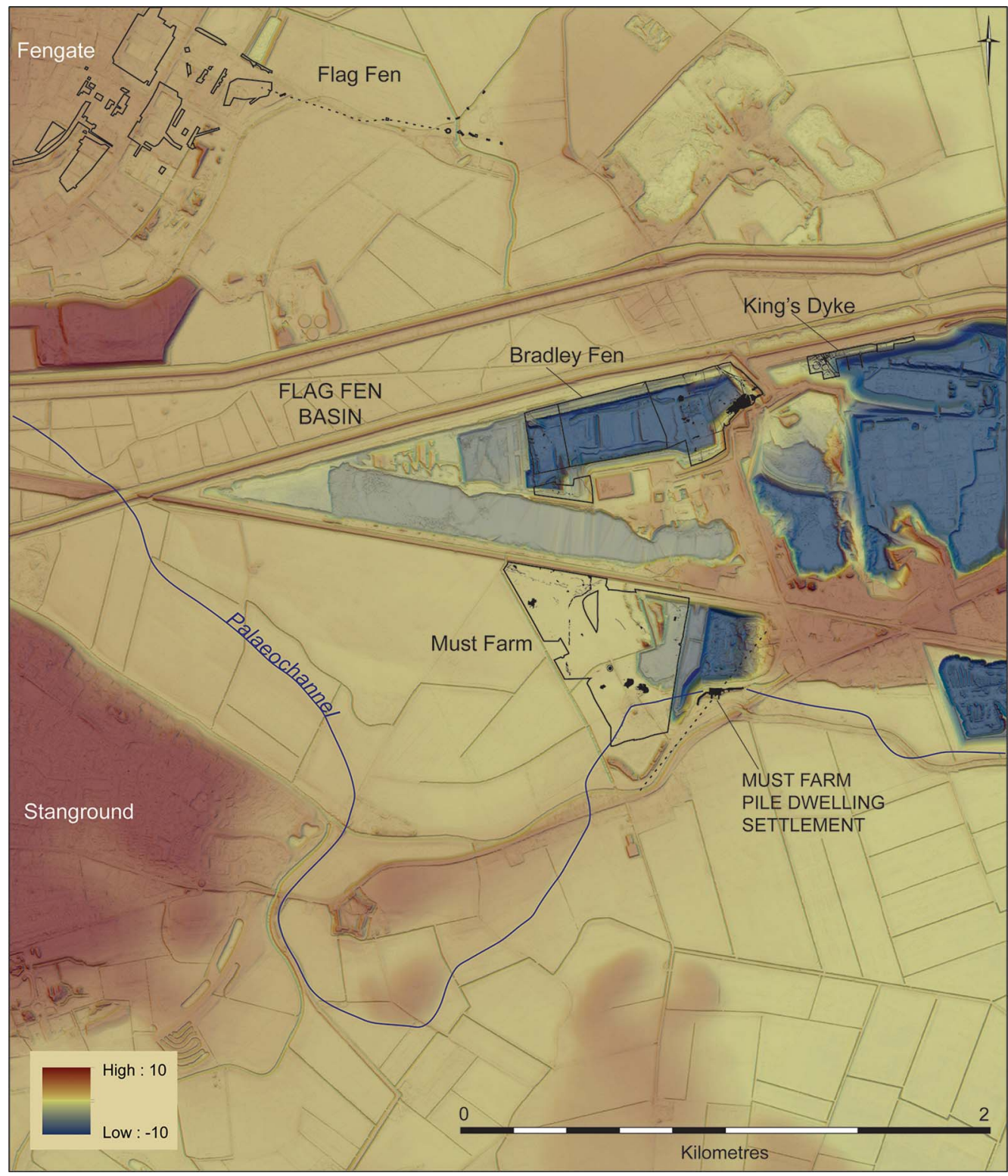

Figure 2. Site location in the Flag Fen Basin (lidar data), with key sites marked (lidar data from Environment Agency LIDAR Composite DTM Im, licensed under the Open Government Licence v3.0; figure arrangement by D. Horne \& V. Herring).

fire-damaged and were confined to a thin 300mm-deep horizon (Figure 3). A radiocarbon sample of charred foodcrust from a ceramic vessel found within this horizon dated to the end of the Late Bronze Age (Table 1: pot M). This evaluation also revealed an earlier, Middle Bronze Age double-alignment of massive oak piles. Pre-dating the pile-dwelling settlement, this alignment was probably part of a causeway across the south-eastern Flag Fen

(C) Antiquity Publications Ltd, 2019 
Table 1. Radiocarbon dates from the 2004 and 2006 evaluations at the Must Farm pile-dwelling site (Gibson et al. 2010) (calibration: OxCal v.4.3.2 (Bronk Ramsey 2017); IntCal13 atmospheric curve (Reimer et al. 2013)).

\begin{tabular}{|c|c|c|c|c|c|}
\hline Sample material & Lab code & Sample & $\begin{array}{c}\text { Conventional } \\
\text { radiocarbon } \\
\text { age }\end{array}$ & $\begin{array}{l}\text { Calibrated date } \\
\qquad(2 \sigma)\end{array}$ & $\begin{array}{l}\delta^{13} \mathrm{C} \\
(\% o)\end{array}$ \\
\hline Causeway pile & Beta-227132 & $\begin{array}{l}\text { Post 40; } \\
\quad \text { Quercus sp. }\end{array}$ & $2920 \pm 60 \mathrm{BP}$ & $1290-920 \mathrm{cal} \mathrm{BC}$ & -25.3 \\
\hline \multirow[t]{3}{*}{$\begin{array}{l}\text { Palisade enclosure } \\
\text { pile }\end{array}$} & Beta-202662 & $\begin{array}{l}\text { Post } 1 ; \\
\quad \text { Fraxinus sp. }\end{array}$ & $2810 \pm 40 \mathrm{BP}$ & $1060-840 \mathrm{cal} \mathrm{BC}$ & -26.7 \\
\hline & Beta-202663 & $\begin{array}{l}\text { Post } 7 \text {; } \\
\quad \text { Fraxinus sp. }\end{array}$ & $2760 \pm 40 \mathrm{BP}$ & $1010-810 \mathrm{cal} \mathrm{BC}$ & -25.9 \\
\hline & Beta-202664 & $\begin{array}{l}\text { Post 14; } \\
\quad \text { Quercus sp. }\end{array}$ & $2750 \pm 40 \mathrm{BP}$ & $1010-810 \mathrm{cal} \mathrm{BC}$ & -28.7 \\
\hline $\begin{array}{l}\text { Charred foodcrust } \\
\text { from pile-dwelling } \\
\text { destruction } \\
\text { horizon }\end{array}$ & Beta- 243230 & Pot $\mathrm{M}$ & $2700 \pm 40 \mathrm{BP}$ & $930-790 \mathrm{cal} \mathrm{BC}$ & -23.1 \\
\hline
\end{tabular}

Basin (Tables $1 \& 2$ : piles 20, 39, 40 and 42). The causeway is broadly equivalent in date and form to the famous Flag Fen causeway that spans the northern end of the Basin (Pryor 2001).

Initial environmental assessment of the palaeochannel sediments revealed excellent anoxic preservation of organic remains within the wet, circumneutral to slightly alkaline, fluvial silts. The diverse biota identified include diatoms, pollen and spores, plant seeds and fruits, insect exoskeletons, ostracod valves, mollusc shells and vertebrate bones (Gibson et al. 2010). While waterlogged biota, particularly freshwater aquatic to semi-aquatic species, were present throughout the stratigraphy of the palaeochannel sequence, charred plant macrofossils and bones of terrestrial vertebrates were concentrated within the conflagration deposits. This evidence indicated the high potential for both long-term environmental reconstruction and for characterisation of the wider settlement.

\section{Excavation and analysis}

In 2015-2016, a single phase of full excavation, recording and removal of the pile-dwelling was commissioned by Historic England and the landowner, Forterra Building Products Ltd. The site was located on the edge of an active quarry and after a 10-year programme of in situ preservation with groundwater monitoring (Malim et al. 2015), it was uncertain whether the anoxic waterlogged conditions required for preservation could be maintained indefinitely.

An open-area excavation strategy was adopted to reveal the spatial distribution of structures, artefacts and ecofacts within and around the palisaded enclosure in full. A temporary shelter was constructed to ensure controlled conditions for excavation of the anticipated delicate organic remains and intricate contextual detail. Within this shelter, careful 

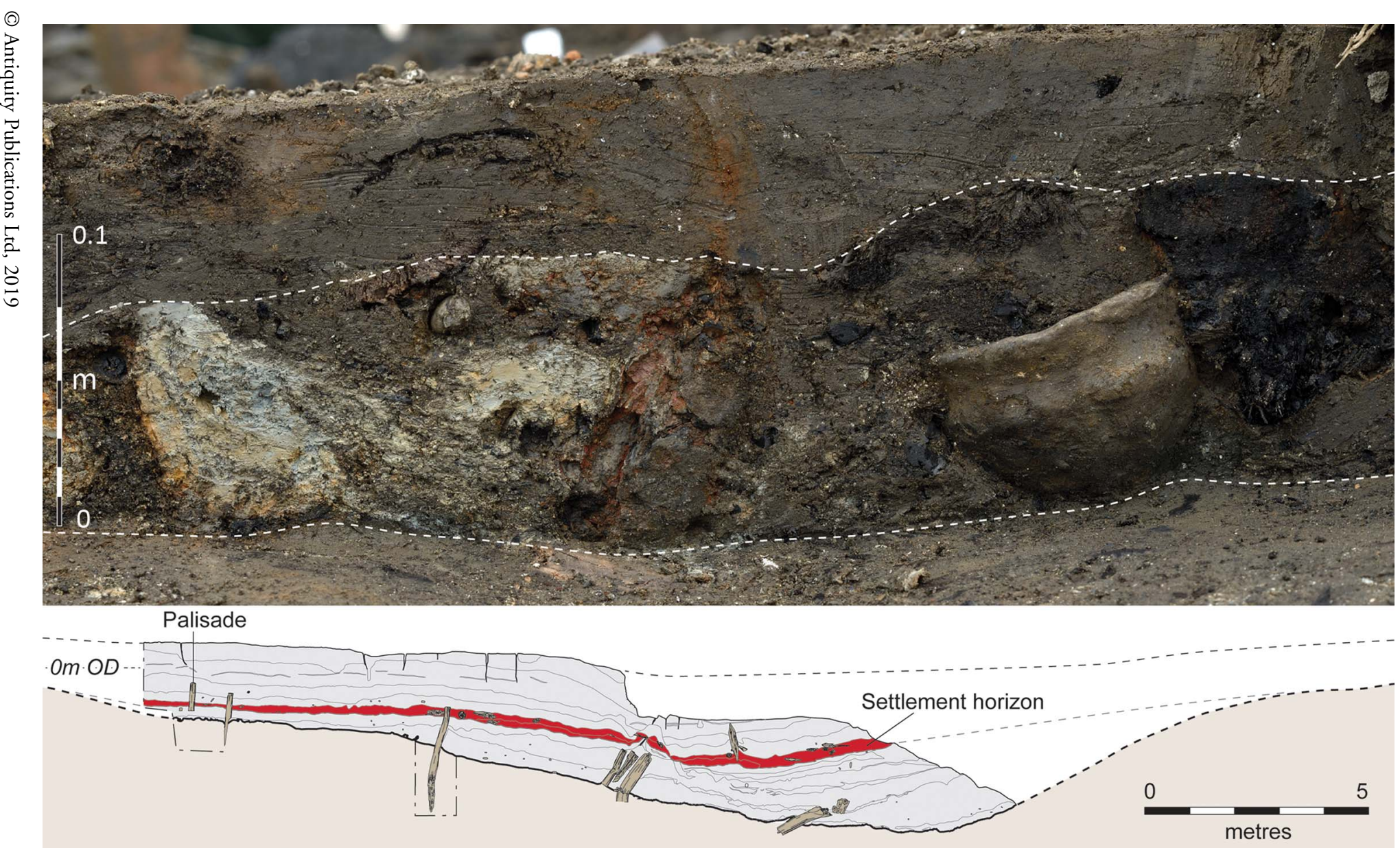

Figure 3. Top) profile of the palaeochannel illustrating the 'settlement horizon' in relation to the surviving channel sediment sequence (photography by D. Webb, figure arrangement by V. Herring); bottom) the 'settlement horizon' in section (figure by V. Herring). 
Table 2. Dendrochronological dates from the 2006 evaluation (Gibson et al. 2010: 80).

\begin{tabular}{lll}
\hline Sample material & Sample & Date \\
\hline & & \\
Causeway pile & Post 20 & Felled after 1290 BC \\
(Quercus sp.) & Post 39 & Felled after 1289 BC \\
& Post 42 & Felled between 1283 and 1247 BC \\
\hline
\end{tabular}

single-context hand excavation of the channel silts was undertaken using a $1 \mathrm{~m}^{2}$ sampling grid, with small- and large-scale temporary baulks employed to investigate contextual relationships. This work uncovered the condensed stratigraphy of the settlement: the collapsed timber superstructure overlying a horizon of fire-damaged material deposited directly onto the settlement's formative middens (created during the brief life of the settlement) and construction debris.

A vast quantity of charred and uncharred structural wood was exposed (Figure 4), revealing the extent to which the architecture of the collapsed buildings had been preserved. The wood mass and associated material culture were recorded using photogrammetry to generate highresolution 3D digital models for the analysis of the construction processes, the use and destruction of the buildings and the spatial distribution of artefacts. Environmental sampling focused on the construction to conflagration deposits for indicators of site character and the use of space, as well as changes in the local environment from immediately prior to construction through to the aftermath of the conflagration. The project further provided an exceptional opportunity to engage with a wide range of audiences via Facebook (https://www. facebook.com/MustFarmArchaeology/), Twitter (@MustFarm) and a dedicated website (http://www.mustfarm.com/bronze-age-settlement/).

\section{Earlier channel activity-weirs, fish trap and timber causeway}

Although the focus of the archaeological investigations was the pile-dwelling settlement, earlier, deeper episodes of channel activity were also exposed. This included additional evidence of Middle Bronze Age fish weirs, which were used during the earliest phase of the freshwater river, and a continuation of the oak timber causeway encountered in the 2006 evaluation trench. Within the excavation area designed to target the pile-dwelling settlement, we were able to explore almost $30 \mathrm{~m}$ of this causeway or river crossing, which comprised two continuous rows of substantial oak piles, augmented by smaller (mainly oak) piles. Excavation of the river sediments associated with the causeway was limited, although a metal-detector survey along the alignment located six pieces of metalwork: two rapiers, two side-looped spearheads, a dirk and a quoit-headed pin. All six objects were located below or at the base of an approximately $400 \mathrm{~mm}$-thick, shell-rich silt horizon, which was stratigraphically located between the end of the causeway's use and the construction of the pile-dwelling settlement. This stratigraphic relationship is important, as it demonstrates that the causeway and the settlement are chronologically unconnected, although the rotting tops of the causeway piles would still have been visible at the time of the settlement's construction.

(C) Antiquity Publications Ltd, 2019 


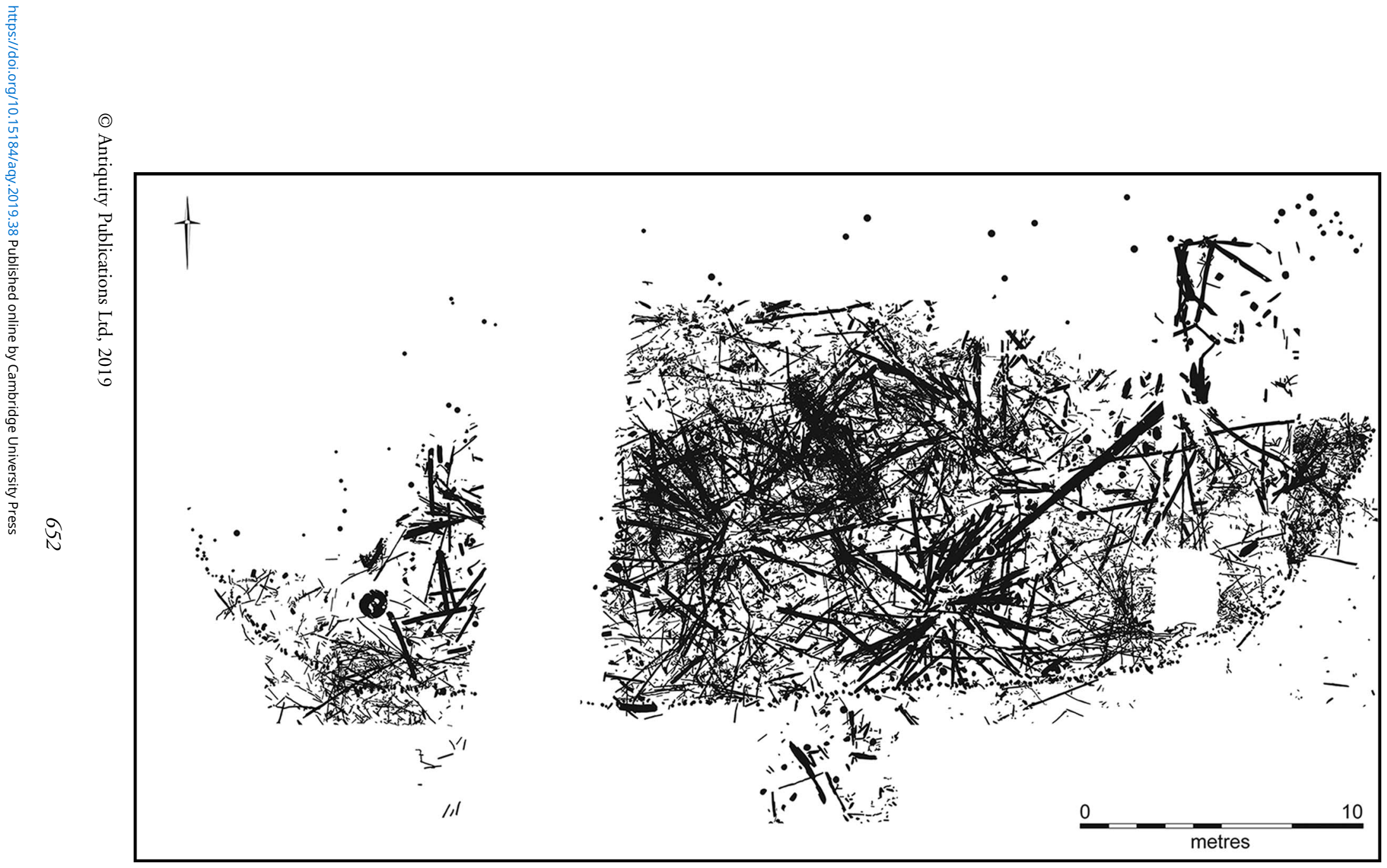

Figure 4. Plan of worked wood (vertical piles and horizontal structural timbers) (figure arrangement by D. Horne \& V. Herring). 


\section{Settlement architecture}

The pile dwelling was constructed when the channel was active but was broad and shallow due to an accumulation of fluvial silts. In plan, the remains of the settlement consisted of hundreds of uprights or pile stumps, which together define the outline and internal settings of at least five stilted structures (structures 1-5) enclosed within a $49.3 \mathrm{~m}$-long, curvilinear palisade with an internal walkway (Figure 5).

The four largest structures were sub-circular, located side by side, in a roughly east-west alignment (structure 3,1,2 and then 5). The boundaries of structures 3 and 1 abutted, as did the boundaries of structures 2 and 5; the $1.75 \mathrm{~m}$-wide interval between structures 1 and 2 was sufficiently large enough to allow room for a raised horizontal hurdle (or wattle-work) gangway. This feature led to the settlement's smallest building, structure 4, which was also the only building to encroach on the enclosing palisade and walkway. This apparently cramped interrelationship suggests that the diminutive structure 4 was an ancillary building, potentially joining the palisaded walkway with the settlement core. Open spaces were rare within the confines of the palisade, and included two small areas, one at the western end of the settlement and one at the eastern end.

Across the settlement, the collapsed timbers revealed a consistent architectural form: structures founded on concentric rings of piles that were deep-set to support large roof timbers and tie-beams, but that also supported comparatively lightweight floors. These floors were raised above the water level and constructed from relatively small diameter poles and hurdle panels. Outside the structures, lightweight poles and slender, mortised timbers formed walkways around the inside of the palisade and amongst the structures. The walkway between structures 1 and 2 was particularly well preserved, comprising a $6 \mathrm{~m}$-long, $1 \mathrm{~m}$-wide hurdle panel supported by stakes and spanning-poles. The contrast between the substantial architecture of each structure's vertical supports, beams and rafters with that of the settlement's floors and elevated walkways can be viewed as a translocation of dryland architecture into a wetland setting. The superstructures appear to have been built according to the conventions of prehistoric British roundhouse construction, which were dictated by the considerable weight of the roof (Harding et al. 1993; Evans et al. 2009: 84).

Coherent reconstruction of each structure's architecture is made possible by the clear spatial patterning of the structural remains. There is no evidence of repair, replacement or the addition of timbers, indicating an absence of remodelling work between construction and destruction. Instead, the collapsed architectural elements resolve into a clear-cut distribution representing just one phase of primary architecture. A single construction episode is confirmed by the presence of thousands of woodchips and larger pieces of debris as a distinct horizon within a single stratigraphic context across the area enclosed by the palisade. That very little sediment-in places just millimetres of silt—separates this construction-debris horizon from the fire-damaged material deposited upon the settlement's collapse indicates that only a brief period of time passed between construction and destruction. This contrasts strikingly with the deeply stratified occupation deposits of the Circum-Alpine lake dwellings. Prior to the catastrophic fire at Arbon Bleiche 3 in Switzerland, for example, there were multiple phases of construction and the formation of approximately 15 years of occupation deposits (Jacomet et al. 2004). 


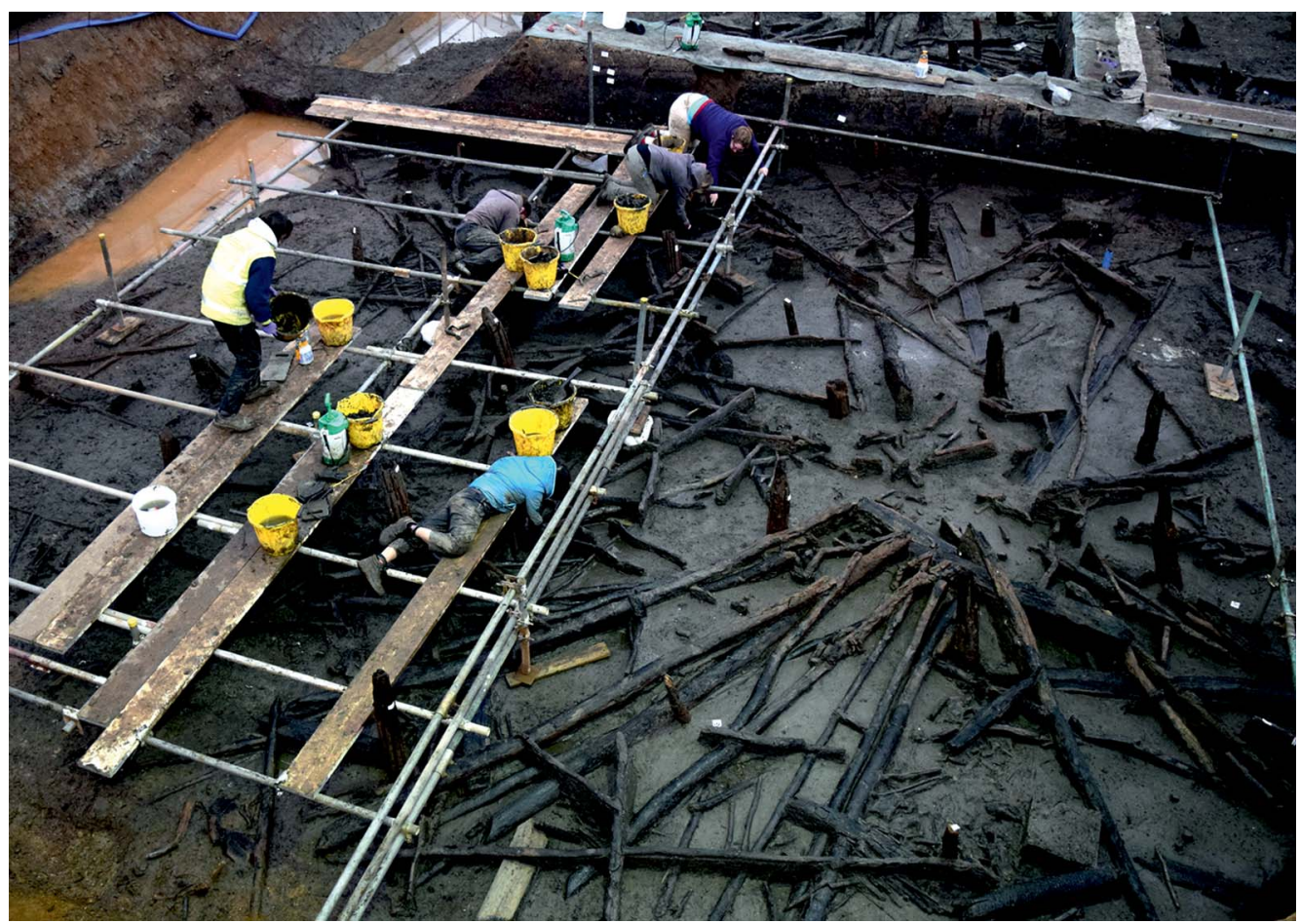

Figure 6. Excavation methodology—scaffold platform above structure 1 (photograph by D. Webb).

At the Must Farm site, the superstructure's untimely and catastrophic demise means that we are able to investigate the undisturbed remnants of an active, functioning pile-dwelling settlement (Figure 6). Its foreshortened life span ensured an absence of later superimposition; as a result, the settlement's brevity is matched by its stratigraphic simplicity. In effect, the entirety of the pile-dwelling settlement is encapsulated in two layers - one representing its construction, the other its demise-with material representing settlement use sandwiched between and amongst the two. Most importantly, the rapid and catastrophic nature of the site's demise has preserved significant elements of the settlement's architectural and spatial organisation. The timber skeletons of individual structures, with fans of subsided rafters and joists, and reoccurring patterns of material culture, suggest that the collapse occurred more or less vertically, with the falling, heavy roof structures bringing everything down with them into the base of the channel.

\section{Material culture}

The stratigraphical simplicity of the settlement contrasts with the mass of structural and material remains identified, and so, the complexity of the site resides in its material intensity: roofing materials, superstructural components, wooden artefacts, pottery sets, bronze tools and weapons, fabrics and fibres, querns, loom weights, spindle whorls, articulated and butchered animal remains, charred plants and seeds, coprolites and an abundance of ecological evidence (Figure 7).

(C) Antiquity Publications Ltd, 2019 


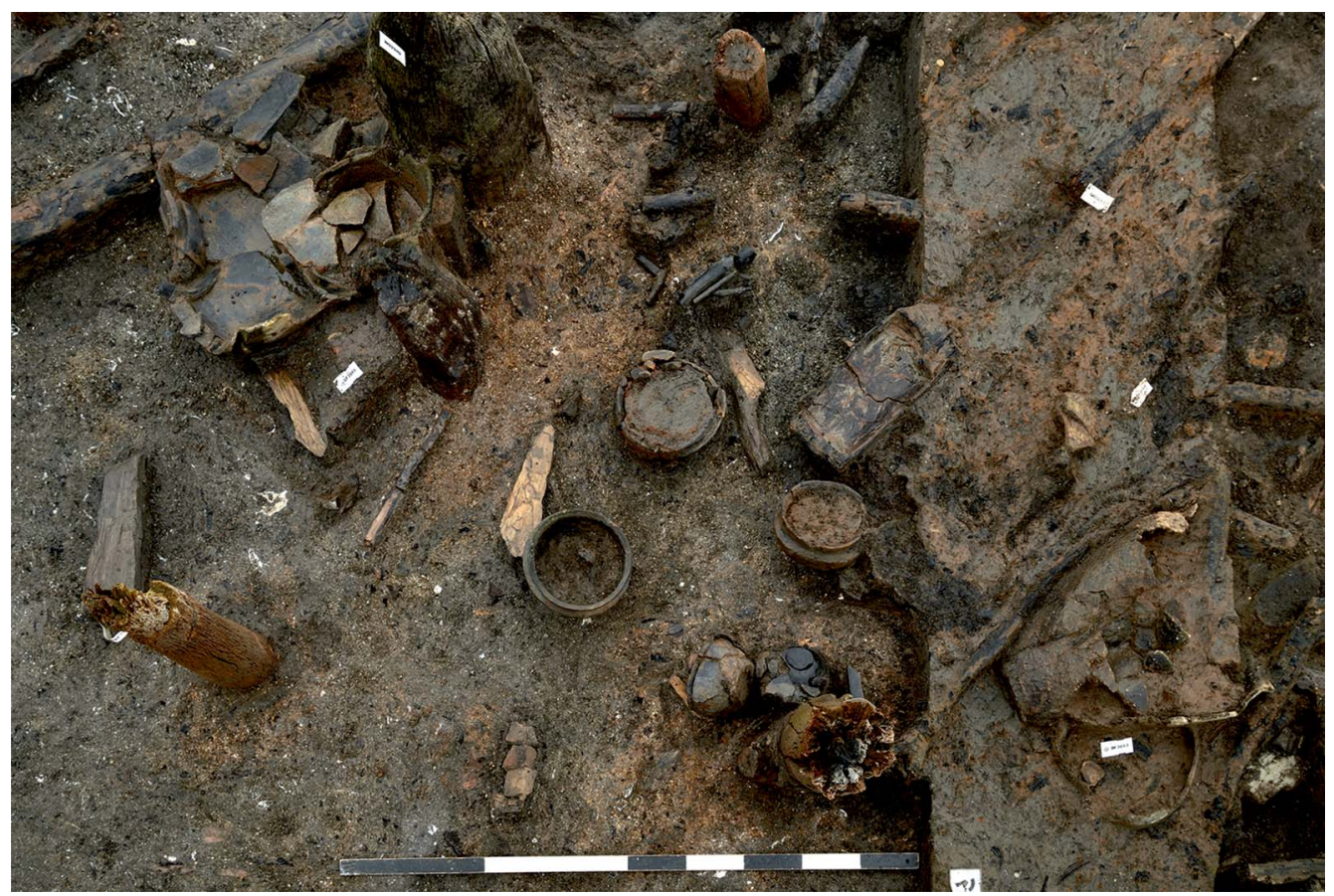

Figure 7. Material culture 'footprint' beneath structures $2 \& 4($ scale $=1 \mathrm{~m})($ photograph by D. Webb).

Remains related to the construction of the settlement consist primarily of woodworking debris, but also include a complete hafted axe (Figure 10). The remains associated with the use of the site were mostly distributed around the footprint of the five circular structures in formative middens, and comprised a scatter of materials, including fragmented pottery, butchered animal bones, redeposited clay, and rounded stones. Spreads or discrete dumps of material-particularly potsherds, animal bone and caches of stones-punctuated the distribution. The resulting spatial pattern was therefore sporadic, as if perhaps representing individual episodes of deposition. The remains associated with the conflagration retained a semblance of their original, above-water setting, probably as a result of the heavily vegetated water body capturing many objects at their points of deposition. The pattern of accumulated material formed a roughly circular heap, equivalent in plan to the footprints of the individual structures, surrounded by arcs of formative middens (Figure 8).

Overall, the inventory of material culture associated with the pile-dwellings consists of hundreds of Late Bronze Age items, including over 180 fibre/textile items (categorised as fibre, textile, twinning and knotted net), 160 wooden artefacts (including bobbins, containers, withies, furniture or fittings, hafts and vehicle parts), 120 pottery vessels, 90 pieces of metalwork and at least 80 glass beads (Figure 10). Notwithstanding this impressive list, the number of loom weights (ten), spindle whorls (eight) and saddle querns (six) appeared to be proportionate to the scale and timeframe of the site, implying that the overall assemblage of material culture was also in proportion to the short-lived settlement. 

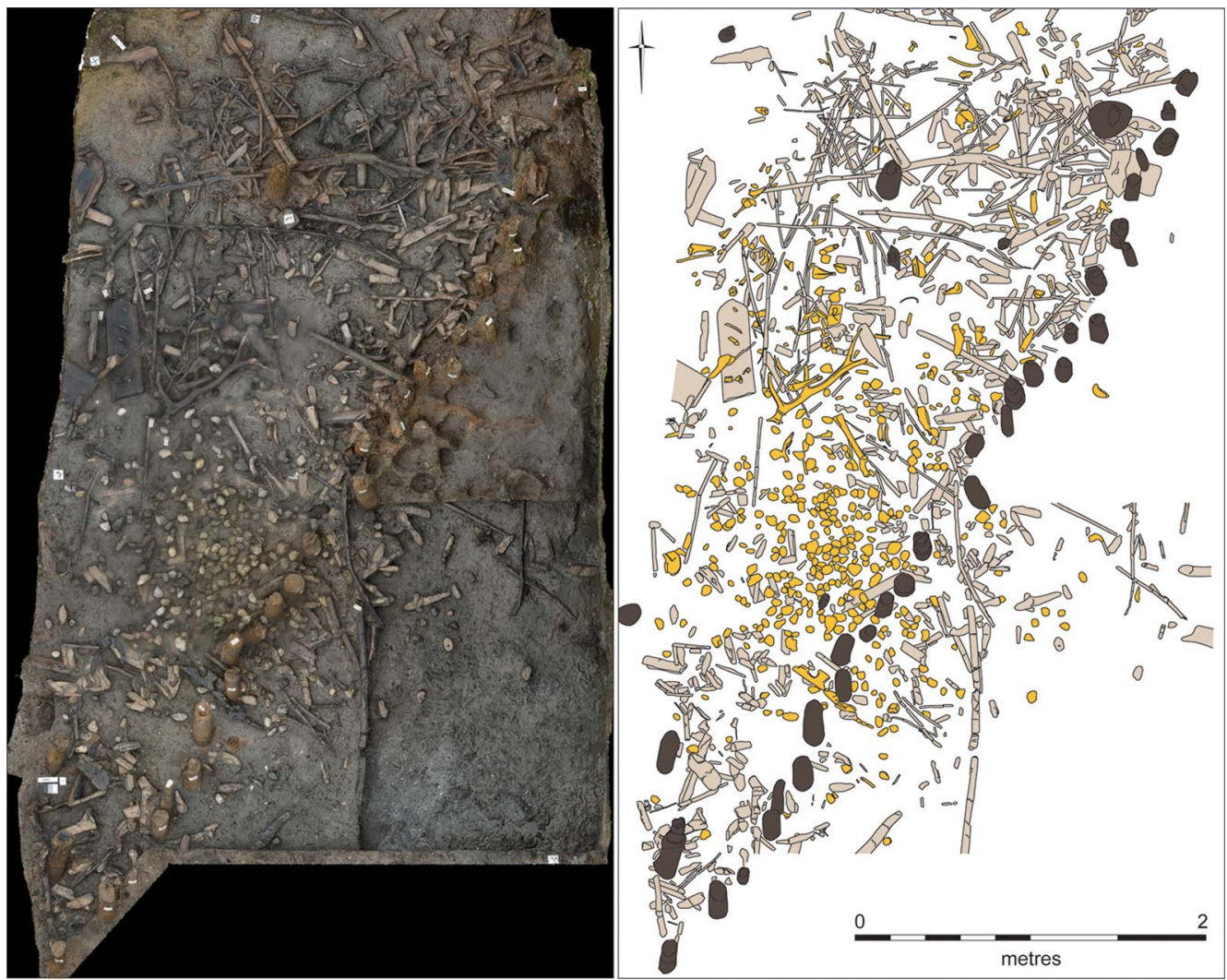

Figure 8. Formative midden deposit inside the eastern perimeter of the enclosing palisade (orthographic image and digitised drawing by $D$. Horne \& $V$. Herring).

\section{Biological remains}

The charred plant and animal assemblages are diverse and sometimes remarkable, including items rarely found in later prehistoric Britain, such as calcined pike bone, charred sheep/goat dung pellets and, currently unidentified, entire charred tubers. Most of the charred biota can be regarded both as organisms to be analysed in terms of their species, habitats, ecology and procurement, and as material culture that was processed, stored, consumed and discarded within the settlement. In contrast, the diverse uncharred plant and animal assemblages represent both habitats in the palaeochannel catchment and resources introduced into the pile-dwelling settlement. While the two categories are not mutually exclusive, the majority of uncharred small biota appear to be organisms from within the palaeochannel catchment.

In contrast to the many uncharred wooden tools, vessels and structural timbers found at the settlement, all of the plant fibres and fabrics are preserved by charring, as are most stem and leaf fragments. There is limited uncharred small diameter roundwood $(<10 \mathrm{~mm})$ or cereal chaff, and uncharred leaves only survive when adhering to durable moisture reservoirs, such as timber or clay surfaces. Thus, brief drying episodes in the palaeochannel (before and after 
the conflagration) appear to have hastened the decay of delicate organics-both ecofacts and artefacts—-such as basketry, matting, nets and textiles.

The preservation of processing tools (featuring microwear), seed caches, meat joints, charred foodcrusts within pots and platters, pot lipid signatures, waterlogged faeces and formative middens offer high potential for addressing diet at the settlement. Most of the food taxa are terrestrial domesticates that are well attested in later prehistoric contexts in Northern Europe, such as emmer wheat, six-row hulled barley, flax, pigs, cattle and sheep/goat (Küster 2018). Wild foods include red deer, wild boar and pike. Although preliminary foodcrust analyses have recovered leaf fragments and fire-affected diatoms, further work is required to investigate whether these microscopic inclusions are intrinsic to the foodcrusts or intrusive from the surrounding burial deposits. The presence of gelatinised starch granules within many foodcrusts, however, is promising for our ability to reconstruct the contents of these ceramic vessels.

There is a striking disparity between the largely terrestrial, dryland food sources and the settlement's watery location. Identification of locally sourced wetland foods, however, is challenging, as the palaeochannel silts include naturally derived assemblages of fish bone and frequent, uncharred seeds of edible plant parts such as blackberries and elderberries. It is anticipated that spatial and temporal analysis of environmental samples may reveal concentrations in the use and conflagration deposits that represent refuse or faeces, rather than natural detritus.

\section{Spatial syntax}

Extraordinary quantities of material culture, processed plant and faunal remains were recovered from within or around the footprints of the structures. Different materials predominated in different spaces and in varied states of fragmentation (Figure 9). Complete ceramic vessels, for example, were found inside the sub-circular structures but never outside. Furthermore, even though the remains of broken vessels were found in both locations, the patterns of breakage indicate that the material outside of the structures was consistently more fragmented. The faunal assemblage is analogous in that articulated elements occurred inside of structures, whereas heavily processed or butchered elements were found outside. Several types of material, such as textiles, grinding stones, seed caches and glass beads, were limited in their distributions to the footprints of the structures. Generally, material situated within the footprints of former structures was fire-damaged, whereas material found outside or between the footprints was not. Thus, in effect there were two distributions: the accumulated debris of construction and use (formative middens), and the collapsed remains of households.

\section{Discussion}

Understanding the character of the pile-dwelling settlement is fundamental for establishing the relevance of these extraordinary remains to wider studies of later prehistoric lifeways. While exceptional in preservation quality and temporal resolution, we argue that this settlement represents a routine dwelling in a rarely excavated fenland setting. As such, it represents

(C) Antiquity Publications Ltd, 2019 


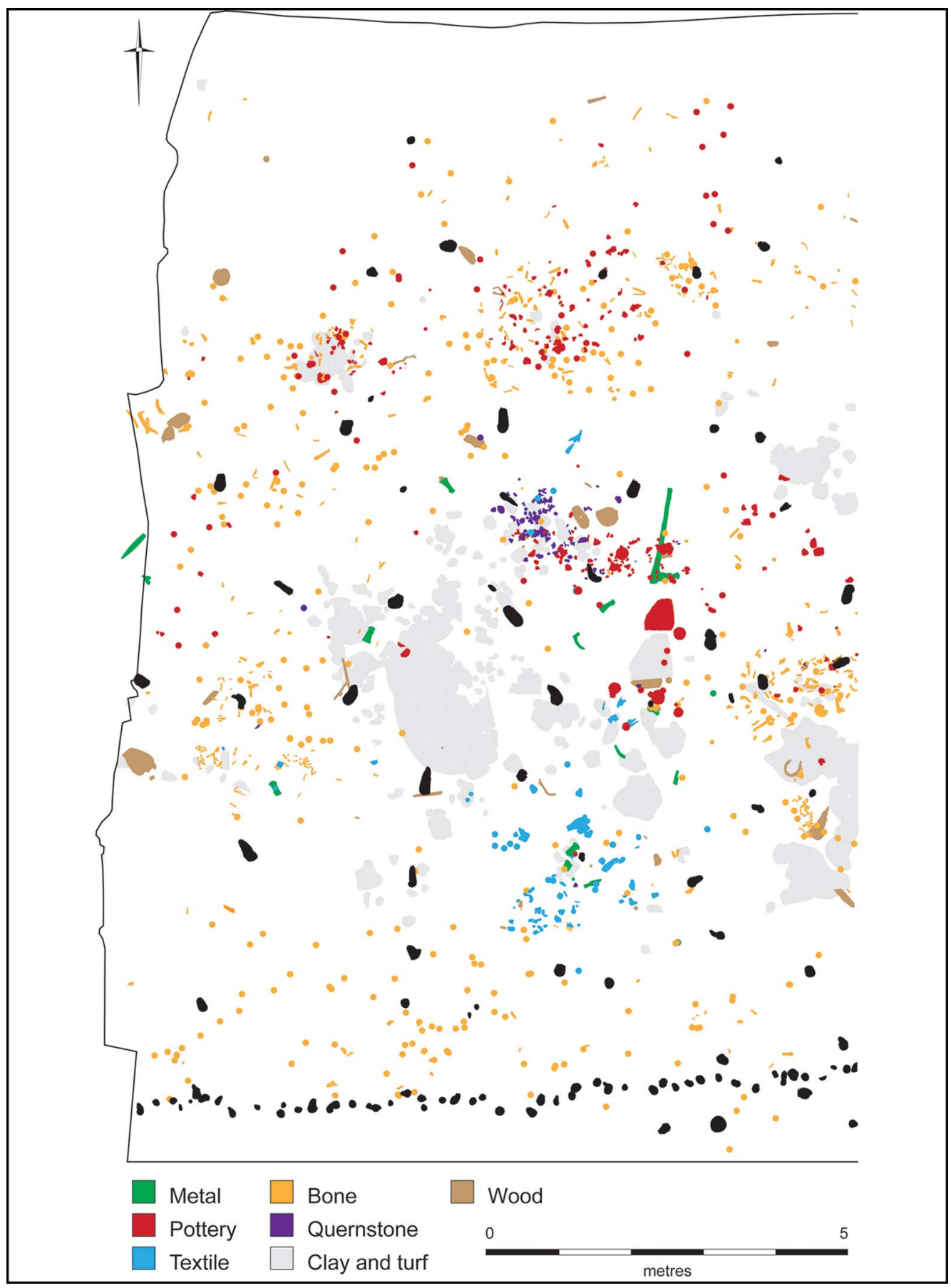

Figure 9. Plan of structure 1 showing the distribution of key material sets (structural uprights in black; figure arrangement by D. Horne \& $V$. Herring). 


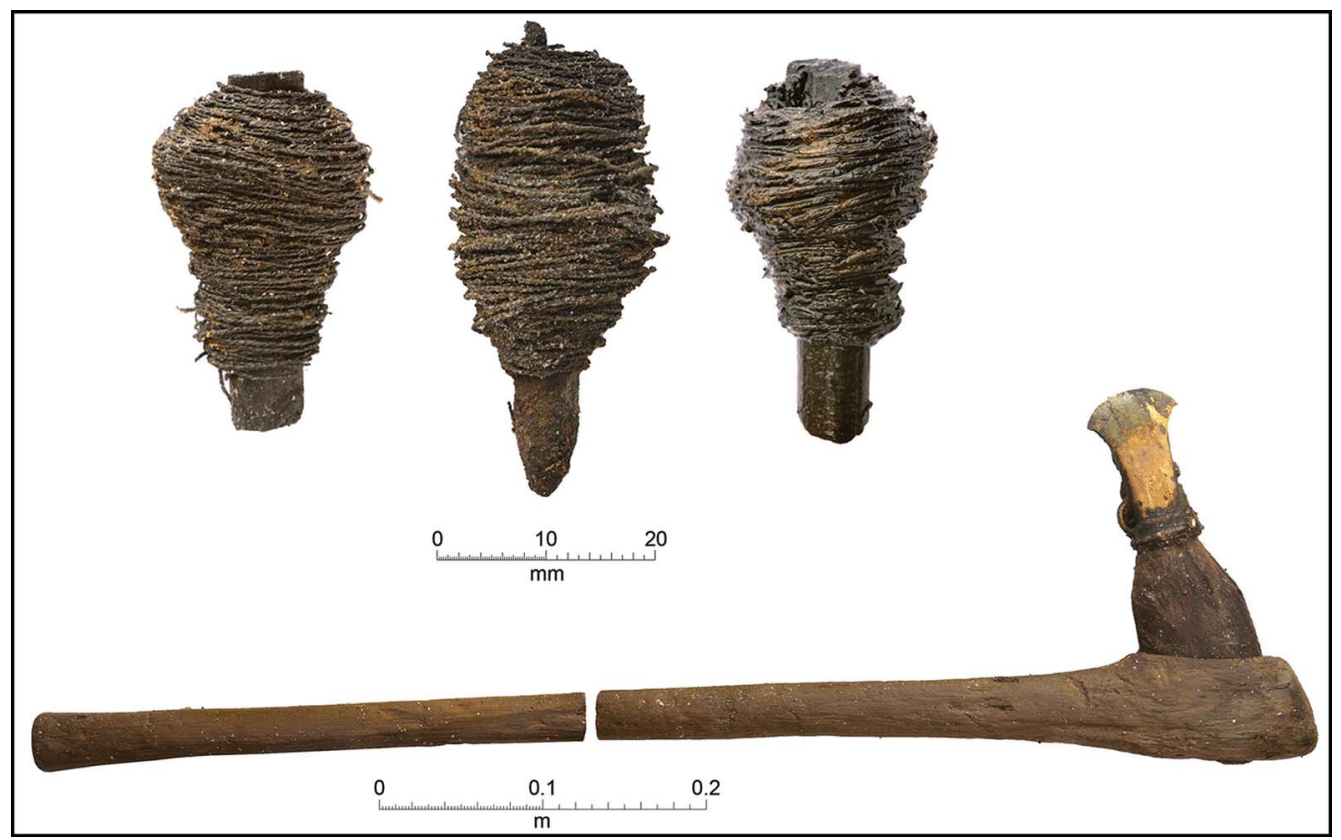

Figure 10. Top) threadlyarn wound around sticks/round dowels; bottom) a complete two-piece axe haft with Ewart Park-type socketed axe (photographs by D. Webb).

the elusive 'control' site (cf. Evans 1989), which directly reflects the actual frequency of organic and inorganic material in a domestic setting.

The thin stratigraphy, architectural clarity and highly structured artefactual and biological assemblages all suggest a brief occupation. The settlement's limited life span is most vividly expressed by the close stratigraphic relationship between the woodchips from construction and the collapsed, charred structural remains of its demise, with the latter resting more or less directly on top of the former.

The emerging evidence suggests that one year is a reasonable estimate for the length of settlement occupation. Ongoing dendrochronological analysis of the structural timbers reveals that the settlement was built in a single construction phase, using wood of a similar felling year. The same analysis also shows differential sapwood shrinkage on areas of individual oaks protected from, and exposed to, the fire, which suggests that the timbers were still green, or unseasoned, when the settlement was destroyed by fire. Oak timber is broadly accepted to require one to two years to season under natural conditions in Britain (I. Tyers pers. comm.). This would provide a terminus ante quem for the duration of occupation, if confirmed by experimental charring of green oak. During excavation, it also became clear that wood-boring insect damage was nearly absent on the structural timbers, despite the retention of sapwood and bark on many elements, including the hurdle gangway. Insects are known to colonise timber structures rapidly; this includes synanthropes, which are also absent in the Must Farm assemblage (Kenward \& Tipper 2008). 
Additional insights into the settlement's temporality are anticipated from the analysis of the vertebrate bones. Preliminary analysis of the juvenile ovicaprids, for example, suggests an age at death of between three and six months (based on first molar eruption), which places their death during the summer months. Such analysis, however, is complicated by the presence of articulated bones from butchered joints, which indicates periods of meat storage, in addition to consumption.

The evidence for settlement temporality and the putative model of one year of occupation provide the potential for defining routine practice and spatial syntax through the chaine opératoire of refitting ceramics (Figure 9) and butchered animal bone. Identifying on-site pathways for these materials should also enhance our architectural reconstructions by refining the footprints inferred for each structure and any potential doorways. Journeys beyond the settlement are evident in the mobilisation of external resources for its construction (e.g. timber, turf and clay), and by some of the items stored and consumed within (e.g. red deer, emmer wheat, flax). The resources and activities characteristic of the Late Bronze Age in dryland areas of Britain were still integral to life in this wetland setting.

Despite being located in the same neighbourhood, the Must Farm pile-dwelling settlement represents a different type of construction to the Flag Fen causeway, both chronologically and morphologically. The settlement dates to around the ninth century BC, while the final phases of construction and maintenance activity at the Flag Fen causeway ceased early in the tenth century BC (Pryor 2001). The causeway was constructed primarily to bridge the north-eastern mouth of the Flag Fen Basin, thus facilitating a dry route between the established Middle Bronze Age field systems of Fengate and Northey Island. The pile-dwelling settlement, however, represents a conscious colonisation of an active waterway, situated within an increasingly saturated landscape that was all but devoid of extant land divisions. This distinction is important, as it positions the settlement within a different kind of landscape investment to the basin- or Fen-Edge settlements that characterised the Middle Bronze Age in this region (Evans et al. 2009). It also raises the possibility that the comparatively ephemeral traces of occupation frequenting the contemporaneous basin-edge also signify a shift from land to water - or to be more precise, a deliberate displacement of settlement to riverine contexts. Seen in this light, contemporaneous pile-built settlements, such as the Upper Thames Valley sites of Wallingford (Cromarty et al. 2006) and Runnymede Bridge (Needham 1991), would appear to show that this movement was not determined by changes in environmental conditions alone. Perhaps these new types of settlement architecture were symptomatic of a need to gain access to and control over river networks.

\section{Conclusions}

The exceptional spatial and temporal coherence of the Must Farm pile-dwelling settlement, together with the particular contextual conditions that preserved its accompanying material intensity, has huge interpretive implications. Along with the ability to reconstruct a Late Bronze Age settlement and its individual household units, the site presents an unparalleled opportunity to explore how its inhabitants "routinely occupied and acted upon their world over time and space" (Barrett 1989: 305). The project has now entered the full postexcavation stage of analysis, which promises a profusion of new material detail, in 
conjunction with much greater spatio-temporal resolution. From this, we should be able to comprehend the scale of occupation, together with its relationship to the wider social and ecological landscape, and, as a result, to articulate tangible patterns of Late Bronze Age consumption - the flow and use of things.

\section{Acknowledgements}

We thank the excavation team, project specialists and support staff for their expertise and dedication. Equally, we acknowledge the significant contribution made by personnel of the funding organisations: Historic England and Forterra Building Products Ltd. The project was monitored by the Historic Environment Team of Cambridgeshire County Council.

\section{References}

BARRETT, J.C. 1989. Food, gender and metal: questions of social reproduction, in M.L.S. Sørensen \& R. Thomas (ed.) From bronze to iron: the Bronze Age-Iron Age transition in Europe (British Archaeological Reports International series 483): 304-20. Oxford: British Archaeological Reports.

-2012. Are models of prestige goods economies and conspicuous consumption applicable to the archaeology of the bronze to iron transition in Britain?, in A.M. Jones, J. Pollard, M.J. Allen \& J. Gardiner (ed.) Image, memory and monumentality: archaeological engagements with the material world (Prehistoric Society Research Paper 5): 6-17. Oxford: Oxbow.

Bronk Ramsey, C. 2017. OxCal v.4.3.2. Available at: https://c14.arch.ox.ac.uk (accessed 28 March 2019).

Cromarty, A.M., A. Barclay, G. Lambrick \& M. Robinson. 2006. Late Bronze Age ritual and habitation on a Thames eyot at Whitecross Farm, Wallingford: the archaeology of the Wallingford Bypass 1986-92 (Thames Valley Landscapes Monograph 22). Oxford: Oxford University School for Archaeology.

Evans, C. 1989. Perishables and worldly goodsartifact decoration and classification in the light of wetlands research. Oxford Journal of Archaeology 8 : 179-201.

https://doi.org/10.1111/j.1468-0092.1989. tb00199.x

Evans, C., E. Beadsmoore, M. Brudenell \& G. LuCAS. 2009. Fengate revisited, further Fen-Edge excavations, Bronze Age fieldsystems and settlement and the Wyman Abbott/Leeds Archives. Cambridge: Cambridge Archaeological Unit.
French, C.A.I. 2003. Geoarchaeology in action: studies in soil micromorphology and landscape evolution. London: Routledge.

Gibson, D.J., M. Knight \& M. Allen. 2010. The Must Farm timber alignments: an archaeological and environmental evaluation. Post-excavation assessment (volumes 1 \& 2) (CAU Report 935). Cambridge: Cambridge Archaeological Unit.

Glass, N. 2016. History made: in an astonishing Bronze Age discovery a 3000-year-old community has been unearthed. CNN, 29 July 2016. Available at: https://edition.cnn.com/style/article/britainpompeii-bronze-age-discovery/index.html (accessed 28 March 2019).

Gray, R. 2016. Was 'Pompeii of the Fens' destroyed in a raid? Village was newly built when it was burnt to ground by Bronze Age warriors. Mail Online, 27 July 2016. Available at: https://www.dailymail.co.uk/sciencetech/article3710616/Was-Pompeii-Fens-destroyed-raidBronze-Age-settlement-newly-built-burneddown.html (accessed 28 March 2019).

Harding, D.W., I.M. Blake \& P.J. Reynolds. 1993. An Iron Age settlement in Dorset: excavation and reconstruction (University of Edinburgh, Department of Archaeology Monograph 1). Edinburgh: University of Edinburgh.

JaComet, S., U. LeuZinger \& J. Schibler. 2004. Die jungsteinzeitliche Seeufersiedlung Arbon Bleiche 3: Umwelt und Wirtschaft (Archäologie im Thurgau 12). Frauenfeld: Departement für Erziehung und Kultur des Kantons Thurgau.

Kenward, H.K. \& J. Tipper. 2008. Insect invaders of reconstructed Anglo-Saxon houses at West Stow, Suffolk, England. Environmental Archaeology 13: 51-57. https://doi.org/10.1179/174963108x279210 
Knight, M. 2009. Excavating a Bronze Age timber platform at Must Farm, Whittlesey, near Peterborough. Past 63: 1-4.

Knight, M. \& M. Brudenell. In press. Pattern \& process: landscape prehistories from Whittlesey Brick Pit - the King's Dyke and Bradley Fen excavations 1998-2004. Cambridge: McDonald Institute for Archaeological Research.

Küster, H. 2018. Food, foodways, and subsistence, in C. Haselgrove, K. Rebay-Salisbury \& P.S. Wells (ed.) The Oxford handbook of the European Iron Age. Oxford: Oxford Handbooks Online. Available at: http://www.oxfordhandbooks.com/view/10. 1093/oxfordhb/9780199696826.001.0001/ oxfordhb-9780199696826 (accessed 28 March 2019).

Malim, T., D. Morgan \& I. Panter. 2015. Suspended preservation: particular preservation conditions within the Must Farm-Flag Fen Bronze Age landscape. Quaternary International 368: 19-30. https://doi.org/10.1016/j.quaint.2014.10.042 Needham, S.P. 1991. Excavation and salvage at Runnymede Bridge, 1978: the Late Bronze Age waterfront site. London: British Museum.

Pryor, F. 2001. The Flag Fen Basin: archaeology and environment of a Fenland landscape. Swindon: English Heritage.

Reimer, P.J. et al. 2013. IntCal13 and Marine13 radiocarbon age calibration curves 0-50 000 years cal BP. Radiocarbon 55: 1869-87. https://doi.org/10.2458/azu_js_rc.55.16947

Robinson, I., M. Knight \& K. Murrell. 2015. Must Farm palaeochannel investigations 20092012. Post-excavation assessment (CAU Report 1266). Cambridge: Cambridge Archaeological Unit.

Received: 25 October 2018; Revised: 12 February 2019; Accepted: 19 February 2019 